\title{
NAPSTER AND NEW ZEALAND: AUTHORISATION UNDER THE COPYRIGHT ACT 1994
}

\author{
Paul Apáthy*
}

This article critically examines the concept of authorisation under the Copyright Act 1994 and considers how New Zealand courts might deal with the issues raised by the Napster litigation in the United States.

\section{INTRODUCTION}

Peer-to-peer networks are posing serious questions about the nature of copyright in the age of the Internet. Napster, one such network based in the United States, became subject to prolonged litigation concerning the legality of a service that assisted users to infringe copyright through the trading of digital music files. Central to the case was the issue of secondary liability, an area of law in which New Zealand differs markedly from the United States. Although Napster was held liable for copyright infringement in the United States, a Napster-type service would escape liability if operating in New Zealand under the current law. ${ }^{1}$

\section{NAPSTER AND THE UNITED STATES POSITION}

\section{A What is a Peer-to-peer Network?}

Standard Internet protocol is based around client/server relationships. This involves a central server holding information at a set location, which individual users access. For example, a normal web page will be stored on a server with a fixed "Internet Protocol" (IP)

* Submitted for the LLB(Hons) degree at Victoria University of Wellington.

1 Jurisdictional issues are beyond the scope of this paper. We will assume all acts relevant to authorisation occurred within New Zealand. 
address. Transfer of information, therefore, only occurs between individual users, ${ }^{2}$ who request information, and the server, which provides it.

A peer-to-peer network, in contrast, does not have a central information reservoir, but instead provides a mechanism for users to find the information they want on the computers of other users. Once the information is found, it may be transferred between the users without the involvement of a central point.

\section{B Napster: A Peer-to-peer Network}

Napster is probably the most famous peer-to-peer network in the world. It is a network designed exclusively for the transfer of audio files in MP3 format. Most of these files are the subject of copyright. ${ }^{3}$

Napster file transfers operate by following this process: ${ }^{4}$

(1) Napster provides free "client" software on its web site that allows users to log on to a Napster server.

(2) Each user logs on and automatically sends a list of their files to the server, which compiles a directory.

(3) Users search the directory for a file.

(4) The server provides a list of matching file names and corresponding IP addresses.

(5) The user selects a file from the list, thereby requesting it from another user.

(6) The file is transferred via "File Transfer Protocol" (FTP) between the two users.

\section{Napster and Copyright Infringement in the United States}

Peer-to-peer network allowed Napster to escape conventional copyright infringement lawsuits. Because Napster did not actually provide the copyright files itself, it could not be

2 Individuals who access the internet via a "dial-up" connection are usually allocated temporary IP addresses for the duration of the dial-up connection. However, some individuals (especially those with high speed connections) also have fixed IP addresses. Peer-to-peer networks are especially helpful in locating information where temporary IP addresses are used.

3 A \& M Records $v$ Napster (2000) 114 F Supp 2d 896, 902-903 (ND Cal). Webnoize <http:/ / www.webnoize.com> (last accessed May 30 2001) calculated that on March 31, 2001 there were approximately 1.21 million users connected to Napster at once. The total user base was several times larger.

4 A $\&$ M Records, above, 905-907. 
held liable for direct copyright infringement. ${ }^{5}$ Theoretically, the copyright holders could sue the individual users who breach copyright. In reality this is very difficult, due to the anonymity of users, the huge number of infringers, possible jurisdictional issues, and the likelihood that infringers will not be deterred. ${ }^{6}$

The more effective method would be to attempt to enjoin Napster under a secondary liability doctrine. In the Napster case, the music industry relied upon contributory infringement and vicarious infringement. ${ }^{7}$

1 Contributory infringement

To establish contributory infringement for copyright in the United States a plaintiff must show: 8

(1) The defendant had knowledge of the infringing activity; and

(2) The defendant induced, caused or materially contributed to the infringing conduct.

The 9th Circuit Court of Appeal decided that Napster could not be held to have constructive knowledge of infringement, ${ }^{9}$ but did have actual knowledge of specific infringing material. ${ }^{10}$ Napster materially contributed to the infringement by providing the "site and facilities" with which users could find and download copyrighted files. ${ }^{11}$

2 Vicarious infringement

To establish vicarious infringement for copyright in the United States a plaintiff must show:

(1) The defendant has the right and ability to supervise the infringing activity; and

5 Websites hosting copyright material have frequently be found in violation of primary copyright infringement. For example: Playboy Enterprises Inc v Webbworld Inc (1997) 968 F Supp 1171 (ND Tex).

6 The music industry also risks alienating those who most want the product. See, for example, Brad King "File-Trading Furor Heats Up" <http://www.wired.com/news/mp3/0,1285,53662,00.html> (last accessed 3 July 2002).

7 A $\mathcal{E} M$ Records, above. For a more comprehensive discussion of the Napster litigation see Clive Elliott "The Napster Saga" [2001] NZLJ 291.

8 Gershwin Publishing Corp v Columbia Artists Mgmt (1971) 443 F 2d 1159, 1162 (2nd Cir).

9 A \& M Records v Napster (2001) 239 F 3d 1004, 1021 (9th Cir). This was based on Sony Corporation $v$ Universal City Studios (1984) 464 US 417.

10 A \& M Records, above, 1022. This was both through discovering it themselves, and by being informed of it by the plaintiffs.

11 A $\mathcal{E} M$ Records, above. 
(2) The defendant has a direct financial interest in such activities.

The court held that the ability to monitor the search indices combined with the right to terminate users' accounts satisfied the supervision requirements. ${ }^{12}$ Napster gained a financial benefit from the infringement because, although it did not make any money from the service, it planned to do so in the future. ${ }^{13}$

The recording industry was therefore successful against Napster on both counts.

\section{PEER-TO-PEER LIABILITY UNDER NEW ZEALAND LAW}

At first glance it is not at all clear whether a service similar to Napster could be held liable in New Zealand (or the United Kingdom). Copyright actions against peer-to-peer networks rely on secondary liability, but the New Zealand law is in most respects much narrower than the United States law. There are four main heads under which secondary liability may be imposed in a copyright situation: ${ }^{14}$ Joint tortfeasance, inducement to commit a tort, vicarious liability, and authorisation.

\section{A Joint Tortfeasance}

Joint tortfeasance is the closest common law doctrine to the United States theory of contributory infringement. Joint tortfeasance is normally traced to Scrutton LJ's judgment in The Koursk, where he endorsed a statement from Clerk and Lindsell on Torts: ${ }^{15}$

Persons are said to be joint tortfeasors when their respective shares in the commission of the tort are done in furtherance of a common design ... [B]ut mere similarity of design on the part of independent actors, causing independent damage, is not enough; there must be concerted action to a common end.

The common design test sets a high threshold. ${ }^{16}$ It tends to require close proximity between the actors, and some degree of common intention. ${ }^{17}$ Mere assistance is not

12 A E M Records, above 1024.

13 A E M Records, above, 1023; (2000) 114 F Supp 2d 896, 921 (ND Cal).

14 It has been suggested that a peer-to-peer network might also face liability under section 37(1) of the Copyright Act 1994. This is untenable because (among other reasons) peer-to-peer networks are not "specifically designed or adapted for making copies" of any particular works.

15 The Koursk [1924] 140, 157 (CA) Scrutton LJ. The passage was endorsed by the New Zealand Court of Appeal in a copyright case: Crystal Glass Industries v Alwinco Products [1986] RPC 259, 268 (CA).

16 "Conspiracy" is often used as a synonym for "common design" in the case law, indicating the level of involvement required.

17 This common intention is to do the act, not commit the tort. See Morton-Norwich Products $v$ Intercen [1978] RPC 501, 515 (Ch D) Graham J. 
enough, as demonstrated by CBS Songs Ltd $v$ Amstrad Consumer Electronics Plc (Amstrad). ${ }^{18}$ In that case, Amstrad, a manufacturer of tape recorders, was sued as a joint tortfeasor (also under inducement to commit a tort and authorisation) with the purchasers of the recorders who used them to copy music. The House of Lords held that there was no common design between the parties, since only the consumer decided whether to infringe copyright. ${ }^{19}$ The same could be said for Napster. The network operators do not know who the infringers are, or what they infringe, let alone share any particular intention with them. The network server provides a list of IP addresses but it is the user who decides whether to infringe by using an address to copy a copyrighted work.

\section{B Inducement to Commit a Tort}

This is sometimes regarded as a species of joint tortfeasance, although it originally arose as a separate duty not to procure a breach of contract. ${ }^{20}$ The principle is best encapsulated in Lord Watson's statement in Allen v Flood: ${ }^{21}$

He who wilfully induces another to do an unlawful act which, but for his persuasion, would or might never have been committed, is rightly held to be responsible for the wrong which he procured.

Procurement has also been distinguished from mere assistance. ${ }^{22}$ Philip Sales has suggested that the distinction is not rational, ${ }^{23}$ but nevertheless the House of Lords upheld the traditional approach in Amstrad: ${ }^{24}$

Generally speaking, inducement, incitement or persuasion to infringe must be by a defendant to an individual infringer and must identifiably procure a particular infringement in order to make the defendant liable as a joint infringer.

18 CBS Songs Ltd v Amstrad Consumer Electronics Plc [1988] RPC 567 (HL).

19 Amstrad, above, 607, Lord Templeman for the Court.

20 Lumley v Gye (1853) 2 E \& B 216; 118 ER 749 (HL).

21 Allen v Flood [1898] AC 1, 106-107 (HL) Lord Watson.

22 Beleggingen Exploitatiemaatscappij Lavender BV v Witten Industrial Diamonds [1979] FSR 59, 65 (CA).

23 Philip Sales "The Tort of Conspiracy and Civil Secondary Liability" [1990] CLJ 491, 507:

In many cases, however, the dividing line between inducing a third party to commit a wrong and assisting him in its commission is so fine as to be non-existent. Often the offering of assistance is itself an inducement to the third party to act wrongfully.

24 CBS Songs Ltd $v$ Amstrad Consumer Electronics Plc [1988] RPC 567, 609 (HL) Lord Templeman for the Court. 
Under this formulation a Napster-type network would escape liability. A peer-to-peer network can and does assist copyright infringement by providing names and addresses, but takes no further steps to procure it. ${ }^{25}$ Like the tape recorder in Amstrad, the Napster network "may be used for lawful or unlawful purposes". ${ }^{26}$ Indeed it would be very difficult for operators of peer-to-peer networks to even identify individual infringements, let alone procure them.

\section{B Vicarious Liability}

Vicarious liability is defined much more strictly under New Zealand law than in the United States. Under the common law, it will only apply when there is a principal/agent or employer/employee situation. ${ }^{27}$ It is therefore impossible to hold operators of peer-topeer networks liable through this doctrine, since the users in no way act as agents for the operators.

\section{AUTHORISATION}

\section{A Introduction}

The question of whether Napster would infringe copyright in New Zealand due to authorisation is particularly difficult. Under the Copyright Act 1994, to "authorise" the copying of a work is a restricted act, and may be an infringement. ${ }^{28}$ However, there have been no cases that have decided the meaning of the word under the Act, and overseas jurisprudence seems confused as to its meaning. An examination of the history and development of the law will therefore be necessary to help ascertain the meaning of authorise before it can be determined whether Napster infringed the Act in this manner.

\section{B Copyright Act 1994}

Under section 29 of the Copyright Act 1994, copyright in a work is infringed by a person who, other than pursuant to a copyright licence, does any restricted act. The various restricted acts are listed in section 16(1), where the final paragraph includes:

(i) To authorise another person to do any of the acts referred to in any of paragraphs (a) to (h) of this subsection.

25 Of course in reality, as Sales, above, points out, facilitating copyright infringement, in a way which makes it easy and unlikely to be punished, acts as a open ended invitation to users to infringe as much as they wish.

26 Amstrad, above, 601, Lord Templemann.

27 For a recent statement of this principle, see Credit Lyonnais Bank Nederland NV v Export Credits Guarantee Department [2000] 1 AC 486, 494 (HL).

28 Copyright Act 1994, s 29. 
Therefore, someone (other than the copyright owner or licensee) who "authorises" the copying of a work (for example) will infringe copyright.

What is meant by authorise? The Act contains no definition of "authorise", although section 2 does contain a definition for "authorised":

'Authorised', with respect to anything done in relation to a work, means done -

(a) By or with the licence of the copyright owner; or

(b) Pursuant to section 62 of this Act:

"Authorise" cannot have a corresponding meaning however, since this would prevent section 16(1)(i) from including any infringement when read in conjunction with section $29 .{ }^{29}$

No cases have examined the meaning of "authorise" under the Copyright Act 1994, and few New Zealand cases have dealt with the word under previous legislation. ${ }^{30}$ Those decisions have relied on foreign authority, cases decided under the copyright legislation of the United Kingdom and Australia. ${ }^{31}$ However, the current leading decisions from these two countries seem inconsistent. In the Australian High Court case of Moorhouse $v$ University of New South Wales (Moorhouse), it was stated that: ${ }^{32}$

... a person who has under his control the means by which an infringement may be committed

- such as a photocopying machine - and who makes it available to other persons, knowing, or having reason to suspect, that it is likely to be used for the purpose of committing an infringement, and omitting to take reasonable steps to limit its use to legitimate purposes, would authorise any infringement that resulted from its use.

29 Under the Copyright Act 1994, ss 16 and 29, acts by the copyright owner done pursuant to a licence or pursuant to the exceptions of Parts III or VIII are not copyright infringements. Since the definition of authorise only contains provisions which fall into one of these three categories, if this definition was given to "authorise", it would be impossible to offend under section 16(1)(i).

30 Australasian Performing Right Association v Koolman [1969] NZLR 273 (SC), Kelly Tarlton's Underwater World v Mellsop (1989) 3 PRNZ 362 (HC), Brintons v Feltex Furnishings of New Zealand [1991] 2 NZLR 677 (HC), Pierson Holdings $v$ Auckland Area Health Board (19 October 1992) High Court, Auckland CP 1867/90, Master Gambrill.

31 Both the Australian and United Kingdom legislation (upon which our own legislation has been largely based) also make it an infringement to "authorise" a restricted act, although the construction of the sections differs somewhat from the New Zealand Act.

32 Moorhouse v University of New South Wales [1976] RPC 151, 157 (HCA) Gibbs J. 
This wide, passive, definition of "authorise" can be contrasted with that given by the House of Lords in Amstrad, which stated that: ${ }^{33}$

... an authorisation means a grant or purported grant, which may be express or implied, of the right to do the act complained of.

A service such as Napster would seem much more vulnerable to the wide approach taken in Moorhouse, than the narrowly defined Amstrad approach. To determine the liabilty of Napster, therefore it will be necessary to examine the development of the law of authorisation, so that it may be possible to decide whether either of these definitions should correctly describe the position under New Zealand law.

\section{Origins of the Copyright Act 1994}

The Copyright Act 1994 is the fourth Copyright Act passed in New Zealand, being preceded by the Acts of 1962, 1913 and 1908. With the exception of the 1908 Act, each New Zealand statute was shortly preceded by a British Act, ${ }^{34}$ and was largely influenced by the changes made in the British legislation. Indeed the Report of the Copyright Committee 1959 recommended that "New Zealand legislation should be similar to the United Kingdom legislation except where the terms of that legislation are not acceptable," so as to allow those who deal with copyright to refer to United Kingdom cases and text books. ${ }^{35}$

The construction of section 16(1) and section 29 does not seem to have relied on either the New Zealand Act of 1962 or the British Act of 1988. Both of these Acts placed "authorise" in the infringement sections, equivalent to section 29 of the Copyright Act 1994. In this regard, the Copyright Act 1994 seems closer to the Copyright Act 1913 and the Copyright Act 1911 (UK) that set out "authorise" in the "sole rights" sections of the Acts. The Copyright Act 1911 (UK) completely overhauled the fragmented copyright regime, which had existed up until that time, and was enacted in virtually identical form by way of the 1913 Act in New Zealand (and similar Acts in Australia and Canada). The 1911 Act was the first to introduce the word "authorise". ${ }^{36}$ Given that there has been no discussion

33 CBS Songs Ltd v Amstrad Consumer Electronics Ltd [1988] RPC 567, 604 (HL) Lord Templeman.

34 The United Kingdom has passed the Copyright Act 1911, Copyright Act 1956, and Copyright, Designs and Patents Act 1988.

35 Copyright Committee Report of the Copyright Committee 1959 (report to the House of Representatives. 1959). It should also be noted that implementation of the Agreement on TradeRelated Aspects of Intellectual Property Rights was also a major concern with the passing of the 1994 Act, although that did not involve matters relating to authorisation.

36 The Copyright Act 1905 (Cth) was actually the first Act to include "authorise", but this Act was quickly superceded by the enactment of the 1911 Act, which was imported into Australia. There is therefore little comment concerning what (if anything) was intended to be achieved by the adoption of "authorise" in the 1905 Act. 
of the alterations to "authorise" since those early Acts, ${ }^{37}$ it seems unlikely that the changes were intended to affect the substance of the law. An understanding of the meaning and purpose of "authorise" will therefore require an examination of the situation which the 1911 Act sought to remedy.

\section{Pre-1911 Law}

Prior to the passing of the Copyright Act 1911 (UK), copyright law was governed by a large number of different statutes that dealt with different classes of works. These Acts, although typically fairly short, were exceedingly confusing. A typical section setting out the rights of copyright holders, is that found in the Dramatic Literary Property Act 1833: ${ }^{38}$

... the [a]uthor of any such production ... [shall] have as his own [p]roperty the sole [1]iberty of representing, or causing to be represented ...

The courts were forced to examine what, if any, secondary liability these statutes created in situations where the alleged infringer did not himself carry out the representing.

\section{Russell v Briant}

The English case of Russell $v$ Briant dealt with this question in relation to musical compositions. ${ }^{39}$ The defendant was the proprietor of a tavern, who hired out a room to an entertainer for the purpose of holding nightly shows. During his shows the entertainer performed two songs to which the plaintiff held the copyright. The defendant's servants sold tickets to these shows, and in one case the defendant himself did also. The question before the court was whether under the Copyright Act $1842,{ }^{40}$ the defendant had represented or caused to be represented the musical compositions. In his judgment Wilde CJ stated: ${ }^{41}$

... we think, - having regard to the object of the Act, and the language of the second section, that no one can be considered as an offender against the provisions of it, so as to subject himself to an action of this nature, unless, by himself, or his agent, he actually takes part in the representation which is a violation of copyright. And, if it be held, that all those who supply some of the means of representation to him who actually represents, are to be regarded as thereby constituting him their agent, and thus causing the representation, within the meaning

37 There is no indication in either the 1959 report or the 1994 reports of any concern with "authorise" or any intention to change its effect.

38 Dramatic Literary Property Act 1833 (UK) 3 \& 4 Vic, c 45, s 15.

39 Russell v Briant (1849) 8 CB 836; 137 ER 737 (QB).

40 Copyright Act 1842 (UK) 5 \& 6, c 15, ss 20-21.

41 Russell, above, 742, Wilde CJ. 
of the $[\mathrm{A}] \mathrm{ct}$, such a doctrine would, we think, embrace a class of persons not at all intended by the legislature.

This was, in effect a limitation of the scope of secondary liability under the "represent or cause to represent" wording to vicarious liability only. One could not infringe copyright unless one either did the act oneself, or had the relationship of principal to the actual infringer. This rule was applied in numerous successive English cases, ${ }^{42}$ although it became clear that one could also infringe jointly if engaged in a partnership with the infringer. ${ }^{43}$

\section{Karno v Pathe Freres}

By 1909, it was becoming apparent that the law, as applied under the Russell $v$ Briant principle restricted liability too narrowly to deal with certain wrongdoers. In Karno v Pathe Freres, ${ }^{44}$ the defendant had made a film version of the plaintiff's play "The Mummy Birds or Twice Nightly", and had hired or sold it to a number of entertainment venues for the purpose of public screenings. It was held, following the Russell $v$ Briant approach, that the defendants could not have represented the work or caused it to have been represented since the people who screened the films were not the agents of the defendants. ${ }^{45}$ It was later noted by Bankes LJ in Falcon $v$ Famous Players Film Co, that "the object of introducing the word 'authorise' [in the Act of 1911] was to get rid of the effect of certain decisions, of which Karno $v$ Pathe Freres was the most recent". 46

\section{E The Copyright Act 1911}

The Copyright Act 1911 (UK) replaced all previous copyright law with a single Act, which both simplified and extended the law. ${ }^{47}$ The old rights and infringement provisions were replaced with two provisions that worked in tandem. Section 1(2) declared the sole rights covered by copyright:

42 See for example, Lyon v Knowles (1863) 3 B \& S 556; 122 ER 209 (CA); Marsh v Conquest (1864) 17 CB (NS) 418; 144 ER 169 (CA); Monaghan v Taylor (1886) 2 TLR 685 (Ch D); Karno v Pathe Freres (1909) 100 LT 260 (CA).

43 Lyon $v$ Knowles, above.

44 Karno v Pathe Freres, above.

45 It was not an infringement at this time to merely copy a dramatic work.

46 Falcon v Famous Players Film Co [1926] 2 KB 474, 491 (CA) Bankes LJ.

47 Copyright Committee Report of the Copyright Committee 1959 (report to the House of Representatives, 1959) 6. 
(2) For the purposes of this Act, "copyright" means the sole right to produce or reproduce the work or any substantial part thereof in any material form whatsoever...

... and to authorise any such acts as aforesaid.

Section 2(1) made any of the acts listed in section 1(2) infringements of copyright if done "without the consent of the owner of the copyright". This basic framework is still used in sections 16(1) and 29(1) of the Copyright Act 1994.

There was much confusion over what legal effect the removal of "cause" and addition of "authorise" had. Macgillivray, a prominent writer on copyright, stated in his text, Copyright Act, 1911, that the words "to authorise any such acts as aforesaid" were superfluous, on the grounds that if someone has the sole right to perform a work, then surely he alone must be the only one who could authorise another to perform it. ${ }^{48}$ The cases that followed struggled with what, if any, meaning should be given to this new word.

\section{F Subsequent Confusion}

The resulting confusion and split in interpretation can be no better illustrated than by two decisions made by the same three Court of Appeal judges, which take completely different approaches, separated by only two years.

1 Performing Right Society v Ciryl Theatrical Syndicate

In Performing Right Society v Ciryl Theatrical Syndicate (Ciryl), ${ }^{49}$ the defendant Faraday was the producer of a play for the Ciryl Theatrical Syndicate, and the licensee of the theatre in which it was performed. The Syndicate employed a band to play music during the performance. In the course of the play's performance, the band played several songs that infringed the plaintiff's copyright. The English Court of Appeal, relying on cases such as Monaghan $v$ Taylor (Monaghan) $)^{50}$ and Lyon $v$ Knowles $^{51}$ decided that Faraday could not have authorised the performances of the songs by the band, since the band members were not his servants or agents. ${ }^{52}$

48 Macgillivray Copyright Act, 1911 (London, 1912) 22.

49 Performing Right Society $v$ Ciryl Theatrical Syndicate [1924] 1 KB 1 (CA).

50 Monaghan $v$ Taylor(1886) 2 TLR 685 (Ch D).

51 Lyon v Knowles (1863) 3 B \& S 556; 122 ER 209 (CA).

52 Ciryl, above, 11, Bankes LJ; 12 Scrutton LJ; 15, Atkin LJ. 
Bankes LJ and Atkin LJ both referred to Monaghan, ${ }^{53}$ a case under the old statutes in which authorisation had been discussed. In that case, Taylor, the defendant, was the proprietor of a music hall. Taylor had hired a singer who had sung on numerous occasions a song to which the plaintiff owned the copyright. Although this would normally be enough to establish agency, and hence infringement on the part of Taylor, his solicitor argued that the singer was not Taylor's agent for the purpose of singing illegal songs. This argument was based on the proposition that authority to act unlawfully should not be assumed from an indifferent statement such as "sing such songs as you please". The argument was unsuccessful, as the Court held that the statement contained a general authority which without further control included copyright songs. ${ }^{54}$ This authority argument is clearly based on a vicarious liability theory. The proposition was stated a few years before Monaghan by Martin B in Wigan Election Petition: ${ }^{55}$

The relation of master and servant imposes upon the master a liability for an unlawful act done by the servant in the course of his employment ... But the ordinary rule with regard to principal and agent is that the principal is only responsible for that which he authorises the agent to do.

The Court of Appeal in Ciryl ${ }^{56}$ seems to have assumed that "authorise" in the Act of 1911 referred to the authority of an agent, ${ }^{57}$ and that no great change was intended in the law, no doubt encouraged by Macgillivray's pronouncement. ${ }^{58}$

\section{Falcon v Famous Players Film Co}

The same Court dealt with authorisation again in Falcon $v$ Famous Players Film Co (Falcon). ${ }^{59}$ An American company made a film of "Held by the Enemy", a play in which Falcon held the English copyright. The English defendants imported the film and through another company let a copy to a cinema for the purpose of public screenings. The

53 Monaghan v Taylor, above.

54 This decision was therefore a standard application of the rules of vicarious liability - that a principal will be vicariously liable if he authorises the act in the course of which the tort is committed, not merely if he authorises the tort itself. See Patrick Atiyah Vicarious Liability in the Law of Torts (London, Butterworths, 1967) 208.

55 Wigan Election Petition (1870) 21 LT 122, 123 Martin B (HC).

56 Performing Right Society $v$ Ciryl Theatrical Syndicate [1924] 1 KB 1 (CA).

57 Indeed, see Ciryl, above, 10, where an example of what would need to be shown to infer authorisation.

58 McCardie J agreed with this assessment in Performing Right Society $v$ Mitchell and Booker [1924] 1 KB 762, 773 (KB).

59 Falcon v Famous Players Film Co [1926] 2 KB 474 (CA). 
defendants relied on Karno $v$ Pathe Freres, ${ }^{60}$ (which involved virtually identical facts), and Ciryl, ${ }^{61}$ which indicated that the law had not changed under the new Act, arguing that there must be a relationship of agency for the defendant to "authorise" the act. The Court of Appeal did not follow their earlier dictum, but instead were of the opinion that the word "authorise" was to be given a much wider meaning than "cause to" had been given under the old Acts.

Bankes LJ and Atkin LJ relied on the cases of Monckton $v$ Pathe Freres (Monckton) and Evans $v$ Hulton (Evans). ${ }^{62}$ In the latter case it was alleged that the defendant had authorised the printing of some detective stories, by selling the rights (which he did not own) to a publisher. Tomlin J resisted the agency argument, holding that this would be "to put too narrow a meaning on the word", noting that the Oxford Dictionary defined authorise as "to give formal approval to; to sanction, approve, countenance". In Falcon, Bankes LJ merely adopted this dicta, but Atkin LJ sought to further define what was meant by Tomlin J.63

For the purposes of this case it appears to me that to "authorize" means to grant or purport to grant to a third person the right to do the act complained of, whether the intention is that the grantee shall do the act on his own account, or only on account of the grantor. [...]

The court, in adopting this new approach made no reference to their earlier judgment in Ciryl, which had the unfortunate effect of leading some later courts to treat the two judgements as compatible.

\section{The two approaches compared}

In one sense the cases are compatible, since application of the Falcon definition of "authorise" in Ciryl would have been unlikely to have lead to a different result. In Ciryl, the defendant Faraday told the orchestra to play music during the intervals between parts of the play. He did not instruct the orchestra what to play, was out of the country during the performances, and stated in a letter to the plaintiffs, "I do not care in the least what they play; it makes no difference to me and indeed I am seriously considering doing without an orchestra at all". ${ }^{64}$ It could hardly be said that in this situation Faraday had approved or sanctioned the orchestra's use of copyrighted music.

60 Karno v Pathe Freres (1909) 100 LT 260 (CA).

61 Performing Right Society $v$ Ciryl Theatrical Syndicate [1924] 1 KB 1 (CA).

62 Monckton v Pathe Freres [1914] 1 KB 395 (KB), Evans v Hulton [1924] WN 130 (KB).

63 Falcon, above, 499 Atkin LJ.

64 Ciryl, above, 5. 
Furthermore, Falcon should not be taken as replacing the Ciryl type of liability with the Falcon definition. Falcon departs from Ciryl on the meaning of "authorise" in the Act, by giving it a new meaning independent of the vicarious liability and joint tortfeasance doctrines that had previously restricted the extent of secondary liability. ${ }^{65}$ The case stands as authority for the principle that if one "authorises" an infringement (whatever definition is given to authorise), then agency will not be necessary. However, prior to 1911 this agency liability certainly could not have relied on the word "authorise", then there is no reason to think that the decision in Falcon abolished it as a separate and distinct form of liability. ${ }^{66}$ Indeed, Scrutton LJ indicated that vicarious liability arises merely from the direct infringement provision: ${ }^{67}$

In my view there is an implied term in the contract that the hirer shall exhibit in order that the sum may become payable to the persons who grant him the right. They have imposed an obligation upon him that he shall perform, and in my view persons who do that perform themselves.

Atkin LJ seems to have best understood the key distinction between the two uses of authorise. In Ciryl an authorised act was an act done in accordance with the defendant's wishes, or done on his behalf. An act authorised in the Falcon sense need not be done on the defendant's behalf at all, but is subject to the defendant's approval. Since this approval is not concerned with the defendant's desire for the act to be done, it must instead be concerned with whether the infringer had the right to do the act. Hence, in Monckton, the defendant authorised the performance of the musical work by selling a record, since the obvious inference of the sale was that the buyer would have the right to play it.

65 This must be contrasted with United States copyright law, where the word "authorise" was specifically used by the legislature to preserve both contributory liability and vicarious liability. See Paul Goldstein Copyright: Principles, Law and Practice (Little, Brown and Company, Boston, 1989) 703-724.

66 The only ground upon which this could be argued, is if it was held that the agency liability under the pre-1911 Acts relied on the wording "cause to". Under the dictum of Russell v Briant this is not strictly necessary. Furthermore there is no reason why the inclusion of "cause to" should have been necessary for imposition of vicarious liability for copyright infringement, when it was not necessary for criminal offences. See Raphael Power The Law of Agency (2 ed, Pitman, London, 1961) 286-288.

67 Falcon v Famous Players Film Co [1926] 2 KB 474, 495 (CA) Scrutton LJ. Also note similar comments in Moorhouse v University of New South Wales [1976] RPC 151, 165 (HCA) Jacob J. 


\section{G Further Confusion - Authorisation, Control and Agency}

Later courts still struggled with these separate concepts. ${ }^{68}$ Although purporting to apply Falcon, many later cases seem inconsistent with it, due in most part to courts overly relying on the somewhat vague words "sanction, countenance and approve". One example of this was the introduction of the "control" test into authorisation cases. This process culminated in the Moorhouse decision.

1 Control and agency

Under the law of agency, control was often cited as an important test in determining whether a relationship of master and servant existed (or whether the infringing party was merely an independent contractor). ${ }^{69}$ McCardie J in Performing Right Society $v$ Mitchell and Booker (Mitchell) stated: ${ }^{70}$

It seems, however, reasonably clear that the final test to be generally applied, lies in the nature and degree of detailed control over the person alleged to be a servant.

The test was therefore of some importance in copyright cases involving vicarious liability, since it helped to determine whether agency existed. ${ }^{71}$

\section{Control and permission}

Control was also held to be a prerequisite to liability under a special provision of the 1911 Act which placed an extra duty of vigilance on hall owners. ${ }^{72}$ Section 2(3) of that Act states:

(3) Copyright in a work shall also be deemed to be infringed by any person who for his private profit permits a theatre or other place of entertainment to be used for the performance in public of the work without the consent of the owner of the copyright, unless he was not aware, and had no reasonable ground for suspecting, that the performance would be an infringement of copyright.

68 One example of this confusion is seen in Australian Performing Rights Association v Miles [1962] NSWLR 405 (SC), who finds the defendants not only vicariously liable, but also directly liable due to a principle he finds authority for in Marsh $v$ Conquest, Monaghan $v$ Taylor and Performing Right Society $v$ Mitchell and Booker.

69 Patrick Atiyah Vicarious Liability in the Law of Torts (Butterworths, London, 1967) 40-41.

70 Performing Right Society $v$ Mitchell and Booker [1924] 1 KB 762, 767 (KB) McCardie J.

71 See, in addition to Mitchell, Lyon v Knowles (1863) 3 B \& S 556; 122 ER 209 (CA), Marsh v Conquest (1864) 17 CB (NS) 418; 144 ER 169 (CA).

72 Performing Right Society v Ciryl Theatrical Syndicate [1924] 1 KB 1, 12-13 (CA) Scrutton LJ. 
A slightly altered version of this provision is contained in section 38 of the Copyright Act 1994. "Permits" has generally been treated as a very broad test for liability, encompassing passive as well as active behavior, and its continuing presence in New Zealand legislation has been controversial. ${ }^{73}$ Scrutton LJ was conscious of the potential for people with little involvement in the infringement to be held liable under this section, holding in Ciryl, "a man does not permit who cannot control". ${ }^{74}$ In Adelaide Corporation $v$ Australian Performing Right Association, Knox CJ and Isaacs J understood this control to be "the power to prevent" the particular act, ${ }^{75}$ while Gavan Duffy and Starke JJ saw permission to do an act "... involving some power or authority to control the act to be done". ${ }^{76}$ Although the exact formulation and subject of this control is somewhat unclear, it certainly includes those who control the use of the location, a class of people which control in the vicarious sense is unconcerned with.

\section{Control and authorisation}

The basis for extending the control element into a test for authorisation is unclear. Control, it is submitted, can be exercised over three things in relation to copyright infringement: the person who infringes, the means by which they infringe, and the place in which the infringement occurs (which might be seen as a species of the second).

Agency is concerned with control of the first type. Since agency is not a requirement of authorisation, to require an authoriser to control the infringer would not only be irrelevant but would unduly limit liability so as to defeat the purpose of "authorise" according to Falcon. ${ }^{77}$

"Permits", in contrast, seems primarily concerned with the third category, control of the place of infringement. Depending on the formulation used it may extend into the first two categories also. Control over the place of the infringement without any statutory indication such as in section 2(3) would seem an altogether arbitrary limitation on the word "authorise", however, and contrary to almost every case that has found authorisation.

73 Copyright Committee Report of the Copyright Committee 1959 (report to the House of Representatives 1959), Department of Justice Copyright Bill: Departmental Report (DOJ/7C/94/365, Wellington, 1994).

74 Ciryl, above, 12-13, Scrutton LJ.

75 Adelaide Corporation v Australian Performing Right Association [1928] 40 CLR 481, 487 Knox CJ; 493 Isaacs J.

76 Adelaide, above, 504, Gavan Duffy and Starke JJ. Although in the context of the section, the "act to be done" is surely to use the theatre, the judges seem to be referring to the performance itself.

77 Falcon v Famous Players Film Co [1926] 2 KB 474 (CA). 
Control over the means of infringement also seems an unlikely ingredient of authorisation. If, for example, control over the means of infringement were necessary in Monckton, then the record seller could not have been held liable for the customer later playing that record in public. However in the Canadian case of Vigneux $v$ Canadian Performing Rights Tribunal (Vigneux) the Privy Council held that Vigneux did not control the public performance of a song on a jukebox, or authorise it merely on this basis: ${ }^{78}$

They had no control over the use of the machine; they had no voice as to whether at any particular time it was available to the restaurant customers or not.

Herring CJ faced a similar situation in the following year in Winstone $v$ Wurlitzer Automatic Phonograph Co (Winstone).$^{79}$ He was clearly perplexed by the Privy Council's decision, and noted the inconsistency in principle with Monckton and Evans, going on to rule that the Privy Council's statements were obiter, since control "was outside of the defences raised and never debated". ${ }^{80}$ He was willing to admit: ${ }^{81}$

It would appear probable, however, that some measure of control of some sort by the person said to have authorised a public performance will usually be found in cases where the inference can properly be drawn that there has been an authorisation in fact.

Several Australasian decisions following these cases relied on the authoriser's control to come to a finding of infringement. ${ }^{82}$ These decisions basically applied Ciryl and the vicarious liability doctrine, but continued to refer to this as "authorise". This further enforced the idea that "control" was a key test of authorisation, although the control in these cases was of the people, not the means.

$5 \quad$ Moorhouse v University of New South Wales

In Moorhouse, both Jacob J (with whom McTiernan ACJ agreed) and Gibbs J relied on a library's control over a photocopier to come to a finding of authorisation. Moorhouse differed from previous cases in that there was neither a relationship of agency between

78 Vigneux v Canadian Performing Rights Tribunal [1945] AC 108, 123 (PC).

79 Winstone $v$ Wurlitzer Automatic Phonograph Co [1946] VLR 338 (SC).

80 Winstone, above, 347, 352.

81 Winstone, above, 347.

82 Australasian Performing Rights Association v Miles [1962] NSWR 405 (NSWSC), Australasian Performing Rights Association v Canterbury Bankstown League Club [1964-65] NSWR 138 (NSWSC), Australasian Performing Rights Association v Koolman [1969] NZLR 273 (SC). 
authoriser and infringer, nor, it is submitted, an express or implied grant of rights to copy the work.

Of the two judges, Gibbs J delineated the control over the means approach more clearly, stating: 83

... a person who has under his control the means by which an infringement of copyright may

be committed - such as a photocopying machine - and who makes it available to other persons, knowing, or having reason to suspect, that it is likely to be used for the purpose of committing an infringement, and omitting to take reasonable steps to limit its use to legitimate purposes, would authorise any infringement that resulted from its use.

The remarkable similarity between this approach and section 2(3) of the Copyright Act 1911 is not coincidental. Gibbs J placed great reliance on Adelaide Corporation $v$ Australian Performing Right Association (Adelaide), ${ }^{84}$ a case concerning the meaning of this section. ${ }^{85}$ Two rather unfortunate comments in Adelaide seem to have led Gibbs $\mathrm{J}$ to equate the meaning of "permit" with "authorise". ${ }^{86}$ He then felt able to import the Adelaide test for the meaning of "permits" under section 2(3) - namely that having sufficient control over the use of the hall so as to be able to prevent a performance, the defendant did not do so. Gibbs J switched the control requirement from the place to the means, and the new test was born. Rather surprisingly, Gibbs J also said that Winstone was "consistent with this view", 87 even though "control" was rejected as a requirement in that case.

Even if the importation of "permit" was valid, the application of the doctrine was skewed by the court. In both Adelaide and Ciryl, the courts suggest that knowledge of the

83 Moorhouse and Another v University of New South Wales [1976] RPC 151, 159 (HCA) Gibbs J. The High Court also said that Mellor v Australian Broadcasting Commission [1940] AC 491 (PC) was consistent with their view, but this case seems of little relevance since it dealt with the scope and applicability of a licence.

84 Adelaide Corporation v Australian Performing Right Association (1928) 40 CLR 481.

85 The Copyright Act 1912 (Cth) imported the Copyright Act 1911 (UK) into Australia.

86 Adelaide, above, 490, Isaacs J noted that: "Like the new word 'authorize,' the word 'permits' is of very extensive connotation. Having international effect, it should not be restricted to narrow limits. Going to the dictionary, as did Buckley LJ (as he then was), for the former word, we find that in the Oxford Dictionary the primary meaning of 'permit' is: 'to allow, suffer, give leave; not to prevent'".

Adelaide, above, 497, Higgins J stated "So far as this position has been stated it is surely idle to talk of the Corporation as 'permitting' the singing of this song. The action has, by consent, been tried on the motion affidavits; and there is not the slightest evidence of any sanction, approval or countenance" given by the Corporation to the performance of the song in question."

87 Moorhouse v University of New South Wales [1976] RPC 151, 159 (HCA) Gibbs J. 
particular act (the work being performed) is necessary to be able to permit it. ${ }^{88}$ Gibbs J seeks to get around this saying "... it is clearly sufficient if there is knowledge or reason to suspect that any one of a number of particular acts is likely to be done" ${ }^{89}$ relying on Winstone. But in Winstone, the defendant company had full knowledge of each of the works in question because it had placed them in the jukebox, thereby impliedly authorising the customers to play any of them. ${ }^{90}$

Jacob J was more cautious in his approach. ${ }^{91}$ He did not rely on Adelaide, but instead referred to both Ciryl and Falcon. In Ciryl, as we have seen, the court assumed "authorise" referred to vicarious liability. ${ }^{92}$ The Court also dealt with permission under section 2(3) of the 1911 Act, and Jacob J (like Gibbs J) seems to equate the two words. ${ }^{93}$ Jacob J's main reasoning lies in three questions, however: ${ }^{94}$

There was no express permission given to him but the real question is whether there was, in the circumstances, an invitation to be implied that he, in common with other users of the library, might make such use of the photocopying facilities as he thought fit.

Is this not an invitation to any user to make such use of the machines as he sees fit and therefore an invitation which extends to the doing of acts comprised in the copyright of authors whose books are on the library shelves? And is not such an invitation an authorising of acts done in response to the invitation?

The first question must clearly be answered in the affirmative, the library clearly allows users to use the photocopiers for their own purposes. The second and third questions contain a barb however. Jacob J argues that an invitation to the user to use the machine as he sees fit includes an invitation to do restricted acts. This is somewhat of a fallacy. The invitation that the university offers is concerned with the use of the machine, which it owns. By inviting library users to use it, the university effectively says the use of this machine is not a conversion. Surely however, by allowing use of the machine the university does not legitimise every possible purpose to which it could be put. Does a

88 Adelaide, above, 487, Knox CJ; 498, Higgins J; 503 Gavan Duffy and Stark JJ; Performing Right Society $v$ Ciryl Theatrical Syndicate 1 [1924] 1 KB 1, 13 (CA) Scrutton LJ.

89 Moorhouse, above.

90 Winstone v Wurlitzer Automatic Phonograph Co [1946] VLR 338, 355 (SC) Herring CJ. The other defendant was held to be jointly liable with the company.

91 In Moorhouse, above, Jacob J.

92 See Part IV F 1 Performing Right Society v Ciryl Theatrical Syndicate.

93 Moorhouse v University of New South Wales [1976] RPC 151, 165 (HCA) Jacob J.

94 Moorhouse, above. 
person who lends a car to a friend, for whatever use he likes, invite him to break the road code? It may be that (although not mentioned) the court was relying on Monaghan (and subsequent decisions) to justify this rationale. ${ }^{95}$ But there the issue was not whether the act was legitimate, but whether the act was done outside the scope of agency. ${ }^{96}$ An employer will be vicariously liable for his employee breaking the road code in the employer's car, if he was using it in the course of employment. Here, however, there is clearly no case of agency.

Jacob J's sleight of hand ends in a similar result to Gibbs J's principle: In both cases control of the means of infringement leads to authorisation of the use to which it is put. The Moorhouse test, it is submitted, is essentially an illegitimate extension of the agency tests used to determine vicarious liability.

Control of a person or thing is not a principle consistent with "authorise" as defined in Falcon, Evans, and Monckton. Control of a person, or even sometimes a thing, can be relevant to establishing agency however. This can be seen in Lyon $v$ Knowles, Marsh $v$ Conquest, and Mitchell. It will only be relevant if it suggests a relationship of principle and agent between the defendant and the infringer for the purpose of the acts in the course of which the tort occurred. Control of a machine might be relevant then, to show that a person was not going beyond the bounds of his or her employment by using it. However the defendant's control of the machine could never by itself be sufficient to render the infringer an agent of the defendant, since this alone would not prove that the act was being done on the behalf of the defendant, as is required to make the actor an agent.

\section{H Policies \& Principles}

Despite various differing interpretations of the word "authorise", few courts have grappled with the purpose which the word "authorise" was intended to serve, and what policy reasons underlie the provision. Judges, it seems, are often perplexed as to why plaintiffs bring actions against alleged "authorisers" instead of the infringers themselves. ${ }^{97}$ McCardie J offered one reason in Mitchell: ${ }^{98}$

A band, however, is often a migratory thing, and an action against it only might be of small avail to the plaintiffs.

95 Monaghan v Taylor (1886) 2 TLR 685 (Ch D).

96 Monaghan, above, 686. See also Part IV above.

97 See, for example, Performing Right Society v Ciryl Theatrical Syndicate 1 [1924] 1 KB 1, 11 (CA) Scrutton LJ.

98 Performing Right Society v Mitchell and Booker [1924] 1 KB 762, 765 (KB) McCardie J. 
Clearly providing plaintiffs with an alternative remedy when the primary infringer disappears cannot be the only justification for this form of secondary liability. However, there has been little discussion of the theoretical basis for authorisation, the courts instead placing their trust in the authors of the Oxford English Dictionary. This might, perhaps, be forgivable if it were to bring clarity to the law, but as Laddie, Prescott and Vitoria lament "this so-called definition replaces one vague expression by another equally vague one".99 With little theoretical foundation, it is unsurprising that the application of the word "authorise" has varied so much.

The introduction of the word "authorise" in 1911 was clearly meant to enlarge the protection granted to copyright holders. The case of Karno $v$ Pathe Freres appears to have concerned the legislators. ${ }^{100}$ In that case the company Pathe Freres had made a film "At the Music Hall" which infringed Karno's copyright in the drama "The Mummy Birds or Twice Nightly" when it screened in the music halls Pathe Freres had sold it to.

The unfortunate effect of the pre-1911 law was to leave the music hall proprietors fully liable for the infringing performances, while Pathe Freres was free to continue to supply the offending product, since the music hall proprietors were not the agents of Pathe Freres. Pathe Freres was therefore not only harming the copyright holders by their actions, but also the music hall proprietors who had to bear the full liability for the infringement.

The result was clearly unjust. The music hall proprietors would assume that having paid for the hire of a film, they would be entitled to screen it, and certainly nothing was said to the contrary. The proprietors relied on the implied right to use the film for the purpose for which it was hired.

1 A warranty analysis

In such a situation it would seem reasonable for the purchaser (or hirer) to rely on the seller to provide these rights. First, the seller would in most cases be in a better position to know whether there is actual permission from the copyright holder to do the act in question. This is because the seller might be the copyright holder himself, an agent of the copyright holder, or have acquired the product in question from the copyright holder. Secondly, there are similar reliances on the rights granted by the seller enshrined in statute. The Sale of Goods Act 1908 provides implied conditions and warranties on the part of the seller that the seller has a right to sell the goods, that the buyer will have a right of quiet possession, and that the goods will be fit for the purpose for which the buyer acquires

99 Hugh Laddie, Peter Prescott and Mary Vitoria The Modern Law of Copyright and Designs (2 ed, Butterworths, London, 1995) 911.

100 Karno v Pathe Freres (1909) 100 LT 260 (CA). See Falcon v Famous Players Film Co [1926] 2 KB 474, 490-491 (CA) Bankes LJ. 
them. ${ }^{101}$ Authorisation, it is argued, provides a similar warranty type protection to those who would rely on the appearance of legitimacy.

It might be argued against this "warranty" analysis that the person authorised is not granted a cause of action per se against the authoriser, as might be expected of a warranty. The Copyright Act 1994 does provide a statutory warranty in certain circumstances, under section 112, however:

(1) Where any person grants a licence for -

(a) The performance, broadcast, or inclusion in a cable programme of a copyright work that is a literary, dramatic, or musical work or a sound recording or film; or

(b) The inclusion of a copyright work that is an artistic work in a performance broadcast, or cable programme,-

(c) There shall be implied a warranty in the licence either-

(d) That the person by whom or on whose behalf the licence is granted is the owner of the copyright in the work, sound recording, or film that is the subject of the licence; or

(e) That the person by whom or on whose behalf the licence is granted is authorised to grant such a licence by the owner of the copyright in the work, sound recording, or film that is the subject of the licence.

Also, a cause of action on the part of the copyright holder clearly protects the person authorised. The potential authoriser would be more likely to warn the potentially authorised of any uses to which the work could not be put, if he too was able to be sued for the other's infringement. ${ }^{102}$

This view of "authorise" is clearly of much benefit to the copyright holder also. In cases such as Karno, ${ }^{103}$ the primary infringer is not the primary wrongdoer. Without a cause of action against parties such as Pathe Freres, copyright holders could sue endless primary infringers to no avail, since Pathe Freres could still continue to profit by enticing others to infringe using its material. An action that allows copyright holders to strike at the real

101 Sale of Goods Act 1908, ss 14, 16(a).

102 Also, the actual infringers might be less likely to be sued themselves if there is another party who could be held liable instead.

103 Karno, above. 
cause of the infringement benefits copyright holders greatly by allowing them to enforce their rights efficiently.

This must be balanced with the rights of the potential authoriser. ${ }^{104}$ It would be unjust to give a meaning to "authorise" which would make an individual liable for another's actions if that individual would not be able to anticipate the possibility of being held liable as a result of his actions. Only then would a person be able to obey the law through conscious action. The warranty analysis would only make those liable who, by words or actions, led another to believe that his right to deal with a work extended beyond that which it did in reality. ${ }^{105}$ Furthermore, there would be no liability unless the person was to act upon this implication. ${ }^{106}$ In any situation a party would easily be able to protect himself from potential liability by disclaiming any right to deal with the work in question, and simultaneously protect the other from an unwitting assumption. Thus formulated, the burden that falls upon those who may potentially authorise does not seem overly heavy.

2 Control-an analysis

Other formulations of "authorise" are less able to be justified from a policy viewpoint. The "control" approach of the Australian High Court (which has been shown to be an expansion of the applicability of vicarious liability principles, see discussion above) is problematic. It is difficult to see what benefit this expansion offers to primary infringers. Although they would surely be amply warned of any potential to infringe where the "means of infringement" was under the control of the authoriser, there would be no reason to need this warning unless the control of the means itself suggested a right to copy, in which case the situation would be adequately addressed by the other principle. Admittedly, the copyright holders gain an additional cause of action for a remedy, but this cause of action would be confined to where the authoriser had control of the "means of infringement". This would not assist the copyright holder in cases where these means had been passed on, such as Karno and Monckton, the type of cases which it would seem the 1911 law was meant to remedy.

A further criticism can be levelled at the inherent uncertainty of the test. Infringement of copyright can generally not be achieved without multiple items. Consider, for example, if one was to paint a copy of a copyrighted image. To begin with, a source would be

104 The cautionary approach of the Ilsey Commission should be borne in mind in this regard. Can it be said that the infringement of copyright is sufficiently serious an offence against law or morality to justify the imposition of so serious a burden on the individuals in question? See Copyright Committee Report of the Copyright Committee 1959 (report to the House of Representatives 1959) 60.

105 This is an objective, not a subjective test. See Part IV above.

106 Performing Right Society v Mitchell and Booker [1924] 1 KB 762, 773 (KB) McCardie J. 
needed to copy from, then a paint brush, an easel, a range of paints, and a canvas. How many items must be supplied for there to be the "means of infringement"? If the university library in Moorhouse had not supplied paper with the photocopiers would they still have authorised the infringement? The other aspect of this uncertainty is the vast range of potential means of infringement - virtually anything in a stationery store could be a means of infringement, even if not providing as easy a method as a photocopier.

Finally, it would seem to bring individuals inside the sphere of liability who may have a very tenuous connection with the wrongdoing. If copying occurred in these cases it would not be because something had been done to cause it, but because sufficient steps had not been taken to prevent it. The positive duty to prevent copyright infringement places an onerous, and in many cases unrealistic, burden on those who control the "means of infringement". ${ }^{107}$ The Australian High Court held that the posting of copyright notices on the machines, ${ }^{108}$ a library guide which warned students to obey the Copyright Act, and copies of the Act in photocopying rooms were not sufficient steps to displace the inference.

3 Secondary infringement under the Copyright Act 1994

The Copyright Act 1994 specifically provides for secondary infringement in sections 35 to 39. Section 37 is of particular relevance to the question of authorisation, since it does extend liability to providing or possessing the means of infringement, but only in certain specific circumstances:

37. Providing Means for Making Infringing Copies-

(1) Copyright in a work is infringed by a person who, other than pursuant to a copyright licence,-

(a) Makes; or

(b) Imports into New Zealand; or

(c) Possesses in the course of business; or

(d) In the course of a business or otherwise, sells or lets for hire; or

(e) In the course of a business, offers or exposes for sale or hire-

an object specifically designed or adapted for making copies of that work, knowing or having reason to believe that the object is to be used to make such infringing copies.

107 This is particularly onerous given that "means of infringement" is potentially such a wide class.

108 Admittedly, these referred to the wrong section, but surely the inference was still that copyright should be complied with. 
The Department of Justice Report on the Copyright Bill 1994 notes that the words "that work" were specifically chosen to limit liability for the means of infringement to "dies, moulds and the like which are to be used to copy a specific copyright work". ${ }^{109}$ Likewise a control requirement could be read into section 38,110 which holds people liable who "... gave permission for that place to be used for the performance ..." However, this section is specifically limited to infringements by performance in places of public entertainment.

Can "authorise" be read so as to cover areas excluded from the ambit of these fairly narrow secondary liability sections? Interestingly, authorisation is actually regarded as a form of primary infringement due to its inclusion under section 29 of the Act. In substance, authorisation seems closer to the secondary infringements since it deals with conduct which causes primary infringements by other people. However, the secondary liability sections are, in effect, anomalous extensions of copyright liability beyond the primary infringement rules designed to deal with specific concerns. Authorisation, on the other hand, is not restricted to any particular circumstances, but functions much more as a basic principle of copyright. In this regard, the placement of authorisation among the primary infringements seems justified. It also highlights the danger in extending the ambit of "authorisation" too far. To give "authorise" a meaning which would encompass any situation where the authoriser controlled a means of infringement would undermine the role of these secondary liability sections as limited extensions of liability beyond the primary liability grounds to deal with specific problems.

\section{Licences and Authorisations}

Treatises of the law have sometimes been criticised in regard to the compartmentalised approach they take to their subjects. Copyright seems to have shared this misfortune since although licences and authorisations are very similar concepts they are virtually never discussed together. It is submitted that the law relating to licences is of great value in carving some clarity out of the vague definitions that have been given to "authorise".

As we have seen, "authorised" acts are not infringements. ${ }^{111}$ What then is the meaning of "authorise" in section 16, which taken with section 29(1), must refer to at least some

109 Department of Justice Copyright Bill: Departmental Report (DOJ/7 C/94/365, Wellington, 1994$) 45$.

110 Copyright Act 1994, s 38 is the successor to Copyright 1911 (UK) s 2(3). For discussion of control requirements under this section see Performing Right Society v Ciryl Theatrical Syndicate [1924] 1 KB 1, 12-13 (CA) Scrutton LJ.

111 Copyright Act 1994, s 2:

"Authorised", with respect to anything done in relation to a work, means done-

By or with the licence of the copyright owner; or Pursuant to section 62 of this Act. 
infringements? It seems reasonable to suppose some level of correspondence in meaning between "authorise" as used in section 16 and an "authorised" act done according to a licence.

All the acts in section 16 are the prerogative of the copyright holder. Exactly the same act conducted by another person will infringe copyright (if not done pursuant to a licence). An "authorised" act is done either pursuant to licence, pursuant to statute, or by the copyright holder. ${ }^{112}$ Therefore to "authorise" an act one must either grant a licence, pass an appropriate law, or assign the copyright. Since only Parliament can pass or amend a statute, the only way individuals can authorise an act is to grant a licence or assign the copyright. Only a copyright holder can assign copyright or grant a licence. ${ }^{113}$ This corresponds with section 16 which is constructed on the premise that restricted acts are acts which only the copyright holder (or someone pursuant to a licence) can do, and are therefore infringements if done by others. ${ }^{114}$ The infringements covered by section 16(1)(i) must therefore occur where someone has acted in such a way that a licence would have been granted, or the copyright assigned, if that person had actually had the authority to do so. As Gummow J put it::115

It might be thought that authorisation was a statutory tort catching those who purport to have power or authority to license the activity of the primary infringer and that it was concerned with appropriation of the right of the copyright owner to license the acts comprised in his or her copyright.

The first observation, upon coming to this conclusion, is that the approach taken by Atkin LJ in Falcon, and the House of Lords in Amstrad, that "'authorize' means to grant or purport to grant to a third party the right to do the act complained of", must be correct under New Zealand law (although subject to some further points I will add).

Secondly, this solution appeals to common sense. Both an authorisation and a grant of a licence can be done either expressly or impliedly. Both seem to involve the same sort of approval concept. Throughout both the caselaw and legislation, the person who grants the licence is often said to "authorise" the act. It would seem strange if a copyright holder could grant a licence to do an act but not be said to authorise it, or vice versa.

Finally, it is now possible to resort to a new branch of case law to help resolve the question of where an authorisation takes place. Licence case law enables a final objection

112 Copyright Act 1994, s 2 "Authorised".

113 With the exception of some licencees, see Copyright Act 1994, s 2 "Copyright licence".

114 Copyright Act 1994, s 29.

115 WEA International v Hanimex (1987) 10 IPR 349, 361 (FCA) Gummow J. 
to the "grant of rights" approach to be disposed of. Laddie, Presott and Vitoria consider the test uncertain: 116

The reference to granting or purporting to grant the right to do the act complained of seems to contain a confusion between two different concepts: (a) It cannot properly be a reference to the purported granting of the 'right' to use the copyright work, for this does not occur where both parties know perfectly well that a piratical use is intended, yet in such cases liability clearly arises. (b) If, however, it is meant that the supplier of one of the essential means (eg a film) by which the eventual infringement is perpetrated thereby authorises in the sense of granting his authority to use the thing, the case cannot be distinguished from Amstrad itself.

In Redwood Music Ltd $v$ Chappell \& Co Ltd (Redwood), ${ }^{117}$ Robert Goff J held that in determining whether there had been an implied grant of licence, the test to be applied

... was an objective one: viz. whether viewing the facts objectively, the words and conduct of the alleged licensor, as made known to the alleged licensee, in fact indicated that the licensor consented to what the licensee was doing.

Since the test is objective, it would not matter what either party knew, but only what they communicated to the other via words or conduct. If the parties did communicate between themselves that a piratical use was intended, there would no longer be an objective authorisation. There would, however, be enough evidence to support the inference that the parties had a common intention to commit the act, and (so long as there was some act of assistance) the "licensor" would in fact be liable as a joint infringer. ${ }^{118}$

\section{J Modern Cases}

\section{$1 \quad$ CBS Songs v Amstrad}

Lord Templeman's statement, that "an authorisation means a grant or purported grant, which may be express or implied, of the right to do the act complained of", seems consistent with the principles previously discussed. One caveat, I think, must be placed on this definition, in light of these principles. Even if a person disclaims any right in themselves to grant another the right to do the act complained of, they may still authorise the act if they purport to know that the other has the right to do the act already. Although this is not technically a grant of licence or assignment of copyright, it would be desirable, due to the "warranty" principle, for a person who holds himself out to know the state of

116 Hugh Laddie, Peter Prescott and Mary Vitoria The Modern Law of Copyright and Designs (2 ed, Butterworths, London, 1995) 913, footnote 4.

117 Redwood Music Ltd v Chappell \& Co Ltd [1982] RPC 109, 128 (QB) Goff J.

118 See Part III above. 
copyright to be held liable, should people infringe in reliance of this assurance. This could be achieved consistently by referring to the law of estoppel. As Lord Birkenhead stated in Maclaine v Gatty: ${ }^{119}$

Where A has by his words or conduct justified B in believing that a certain state of facts exists, and $B$ has acted upon such belief to his prejudice, $A$ is not permitted to affirm against $B$ that a different state of facts existed at the same time.

Therefore, should the copyright holder tell someone that although they did not have the power to grant a licence, the act would not infringe copyright, and the person relied upon this statement, then the copyright holder would not be able to claim that the act did infringe copyright. It seems a reasonable assumption that a licence was granted by this statement, since the act was effectively made legal. ${ }^{120}$ If a licence can be granted, and therefore the act authorised, by the copyright holder's assurance of legality, then such an authorisation would surely be an infringement if made by a person other than one entitled to grant the right.

\section{$2 \quad$ New Zealand cases}

Only three cases in New Zealand have ever addressed the meaning of "authorise" under copyright legislation in any depth: Australasian Performing Right Association v Koolman (Koolman), Brintons $v$ Feltex Furnishings of New Zealand (Brintons), and Pierson Holdings $v$ Auckland Area Health Board (Pierson). ${ }^{121}$ These cases were all decided under the Copyright Act 1962, and rely almost exclusively on foreign, rather than local, case law.

The Koolman decision relies on reasoning quite similar to Moorhouse, in that authorising was equated with permitting. ${ }^{122}$ The court applied a "control" approach, but based on the premises, not the infringers. In Kelly Tarlton's Underwater World v Mellsop, the Court noted that the Koolman decision would have to be reconsidered in the light of Amstrad. ${ }^{123}$

In Brintons, Hillyer J decided that the defendant did not authorise the copying because of a "fundamental principle that there can only be copying if the infringer knows he is copying". ${ }^{124}$ The judge gave no authority or reasons for this "fundamental principle". The

119 Maclaine v Gatty [1921] 1 AC 376, 386 (HL).

120 A licence only makes an act lawful which without it would be unlawful.

121 Australasian Performing Right Association v Koolman [1969] NZLR 273 (SC), Brintons v Feltex Furnishings of New Zealand [1991] 2 NZLR 677 (HC), Pierson Holdings v Auckland Area Health Board (19 October 1992) High Court, Auckland CP 1867/90, Master Gambrill.

122 Koolman, above, 275-276.

123 Kelly Tarlton's Underwater World v Mellsop (1989) 3 PRNZ 362 (HC).

124 Brintons, above, 681, Hillyer J. 
principle is, in fact, contrary to the damages provisions of the Copyright Act 1962 which allows for lesser damages where the infringer was not aware of the breach. ${ }^{125}$ The judgment is probably best ignored.

In the Pierson case, Master Gambrill relied on the Amstrad approach, stating that the issue would be whether "the board conferred on the maker the power to copy or whether it granted or purported to grant the right to copy". ${ }^{126}$ The discussion and reasoning is fairly brief.

Although by no means conclusive, the current state of New Zealand case law, therefore, seems to support the Amstrad approach.

3 Australia

Even in Australia, the Moorhouse decision has not passed without question. In WEA International $v$ Hanimex, a case decided before the House of Lords decision in Amstrad, Gummow J noted the criticism of the Moorhouse approach, but continued: ${ }^{127}$

Be that as it may, the position in Australia with respect to the 1968 Act is presently settled by

Moorhouse's case.

4 Conclusion

Amstrad seems much closer to the correct interpretation of "authorise" than Moorhouse. The original aim of "authorise" was to deal with individuals who represented themselves as having a greater right to a work than was the case, and thereby, led others to infringe. However, this principle was confused with earlier vicarious liability decisions and contemporaneous "permission" provisions, leading some courts to apply a variety of hybrid "control" tests. The principles behind these tests were confused, and in some cases, clearly contradictory to the original purpose of "authorise".

Courts meanwhile had failed to recognise the key relationship between licences and authorisations. The wording of the Copyright Act 1994 makes this relationship impossible to ignore, and helps define the workings of the "authorise" test.

The reliance by the Moorhouse court on confused cases and vague authority led to a "definition" of authorise unintended by Parliament and unjustified in principle or policy.

125 Copyright Act 1962, s 24(2). See also Copyright Act 1994, s 121(2) and Francis Day \& Hunter Ltd v Bron [1963] 1 Ch 587 (CA), where the court held that knowledge was not necessary to infringe copyright on the basis that a work could be copied subconsciously.

126 Pierson Holdings v Auckland Area Health Board (19 October 1992) High Court, Auckland CP 1867/90, 5, Master Gambrill.

127 WEA International v Hanimex (1987) 10 IPR 349, 362 (FCA) Gummow J. 
In contrast, by adopting the "grant of right" test, the court in Amstrad correctly interpreted the approach of the English Court of Appeal in Falcon, ${ }^{128}$ and thereby, adopted the meaning of authorise intended by the legislature when first introduced in 1911.

\section{K Application to Napster}

It is, I think, fairly clear that Napster at no stage expressly authorised the copying of any work. The question rather is whether Napster, either by words or conduct, impliedly did so. The test is objective, based on the words and conduct communicated to the infringer. ${ }^{129}$ Did the communicated words and conduct create an objective appearance of consent to the action?

In determining this, three factors are likely to be particularly relevant. The first and most important factor is whether the person appears able to consent. If the person doesn't appear able to consent, then it will be impossible for an objective appearance of consent to exist. The second factor is whether the person appears to have knowledge of the action in question. In most cases it would be hard to say someone consented to something if they did not appear to know about it. The final factor will be whether there was some indication of approval. Whether the approval need be positive words or acts, and if so how clear they must be, would depend, at least, partially on the level of apparent knowledge. In a situation where the person clearly knew of the other's acts and was in close communication, a positive act might not be required at all.

1 Appearance of ability to consent

In many cases the appearance of ability to consent will not be an issue. Where, for example, there is no mention of another's rights, and there is the appearance of approval of the action, there may well be no reason to suspect that there is no ability to consent. If the situation might otherwise suggest a lack of ability to consent, an assurance by the person may lead to an appearance of ability. Therefore, in Monckton and Evans, the provision of the record and manuscripts was enough, without any indications to the contrary, to suggest to the infringers that the provider had the ability to consent to the use of the works.

In the case of Napster the situation is very different. The public, it is submitted, are now much more aware that music copyright is jealously guarded and would be unlikely to automatically assume that the music being provided over the network was done so legitimately. Furthermore, the creators of the Napster software included a disclaimer of

128 Falcon v Famous Players Film Co [1926] 2 KB 474 (CA).

129 Applying Redwood Music Ltd v Chappell \& Co Ltd [1982] RPC 109, 128 (QB) Goff J, see Part IV above. 
any right to allow users to download copyrighted music via the network, which appears during the installation process. A further similar disclaimer could be added when every network session began. These disclaimers communicate to potential infringers very clearly that Napster has no ability to consent to the copying of any material, and therefore there can be no objective appearance of ability to consent.

\section{Appearance of knowledge}

The importance of appearance of knowledge would, it is suggested, depend somewhat upon the circumstances of the alleged consent and wrongful act. If consent was given in broad terms, then the fact that the authoriser did not appear to have knowledge of the specific acts in question might not be material if they clearly fell within what was consented to. However, if the alleged authoriser would objectively appear not to have even contemplated the act in question when the consent was given, then it would be difficult to argue that the consent did in fact extend to such an action.

Napster had at least a general degree of knowledge of the acts which were conducted on its network. In the Napster case, the Court noted that Napster had been informed of more than 12,000 copyrighted files that had appeared on the network, and that Napster employees had themselves downloaded some copyrighted music. ${ }^{130}$ At the same time it was clear that Napster had no knowledge of individual file transfers. The system worked by providing users with a list of file names which corresponded to search terms. Any file transfer that occurred by using this list occurred directly between the users, without the involvement of the Napster server. To most Internet savvy users, at least, it would be apparent that Napster had no idea what music they were copying. This was compounded by the fact that file names could be (and after filters were imposed this became common practice) deliberately altered by users so as to prevent Napster from being able to match a file name to the name of a copyrighted work. ${ }^{131}$ Objectively then, Napster could not appear to have knowledge of any individual actions, even if they might have a general knowledge of what works were likely to be traded by people. Since Napster did not appear to have particularly specific knowledge of the actions of infringers, it would therefore be necessary to show a consent definition sufficiently broad enough to encompass these actions.

130 A \& M Records v Napster (2000) 114 F Supp 2d 896, 918-919 (ND Cal).

131 One method of doing this was by using specially designed software. See Napcameback <http:/ / www.napcameback.com> (last accessed 6 June 2001). 
What action might be necessary to indicate consent must depend largely upon the circumstances of the case. In a case such as Redwood, ${ }^{132}$ where the copyright holder clearly knew of the use of the specific work due to the payment of royalties, the fact that there was no objection to the use was sufficient to indicate consent. Where there is a contract, courts tend to imply licences that extend to all those activities concerned with the purpose of the contract. ${ }^{133}$ The hire of a film, such as in Falcon, therefore creates an implied licence to screen it. ${ }^{134}$ However, in contrast, it has been held that merely being sent a complimentary copy of a song does not import a licence to perform it in public. ${ }^{135}$ The level of consent which might be reasonably inferred from an individual's words or actions will therefore depend largely upon how overt an approval might reasonably be expected, given the apparent knowledge of the user's actions.

In the case of Napster, there is no express approval. There is a contract between users and Napster concerning use of the Napster software, but no contract concerning any of the copyright works. Napster does provide lists to users of all the files available via the system, which would prima facie seem to be an approval to copy. However, taken with the apparent lack of specific knowledge of what these files are, it seems doubtful that this approval should be viewed as particularly firm. Furthermore, this apparent approval must be counterbalanced with the statements disclaiming authority to consent, and warnings that users who infringe copyright may be removed from the system.

4 Conclusion

It seems impossible to conclude that Napster has authorised the infringements of its users if by "authorise" we refer to an objective conveyance of consent. Users of Napster could not objectively claim to believe Napster had the ability to consent, the knowledge to consent or had manifested any approval that could be taken as consent to the copying of any file.

\section{FINAL CONCLUSION}

Much of this argument has been pre-empted by online events. The liability of Napster in United States courts has not had a major effect on the level of trading in copyright material online. Programmers have devised alternative network frameworks - true peer-

132 Redwood Music Ltd v Chappell \& Co Ltd [1982] RPC 109, 128-129 (QB) Goff J.

133 Hugh Laddie, Peter Prescott and Mary Vitoria The Modern Law of Copyright and Designs (2 ed, Butterworths, London, 1995) 636.

134 Falcon v Famous Players Film Company [1926] 2 KB 474 (CA).

135 Performing Right Society $v$ Coates [1923-28] MCC 103 (HC). 
to-peer networks that involve not only peer-to-peer file transfers but also peer-to-peer file searches, greatly reducing the potential for a central server to be held liable. ${ }^{136}$ This means that New Zealand is unlikely to become a haven for peer-to-peer networks. However, the analysis highlights the nature of secondary liability in New Zealand, and the fact that in this regard at least, New Zealand has surprisingly liberal copyright law.

136 Peer-to-peer litigation continues in the United States, but post Napster, the real battle ground has shifted to issues such as the introduction of "digital rights management" and legislation requiring copy-protection to be included in consumer electronic devices. 
